\title{
Comparison of Upper Extremities of Children Who Playing and Not Playing Basketball
}

\author{
Orhan Ahmet ŞENER 1, E Şerife ALPA²
}

\author{
${ }_{1}^{1}$ Selçuk University, Faculty of Sport Sciences, Physical Education and Sports Department, Konya/TURKEY \\ ${ }^{2}$ KTO Karatay University, Faculty of Medicine, Department of Anatomy, Konya/TURKEY \\ Address Correspondence to: Şerife ALPA mail: serife.cinar@karatay.edu.tr
}

\begin{abstract}
In this study, it is aimed to compare the upper extremities of children who play and do not play basketball. In this study, measurements were taken in the upper extremities of a total of 200 secondary school students playing basketball and non-playing, with a mean age range of $11 \pm 1.08$ (did play sports) - $11 \pm 0.8$ (did not play sports). The average height and weight ratio of the students who did and did not play sports were $153.5 \pm 12.9-149.2 \pm 8.1 \mathrm{~cm}$ and $46.7 \pm 12.04-43.08 \pm 12.9 \mathrm{~kg}$ respectively. In the right and left upper extremities of the students who play sports, arm length was $28.4 \pm 3.1-28.4 \pm 3.01$. the forearm length was 24.1 $\pm 2.4-24.1 \pm 2.4$. hand length was $15.9 \pm 1.8$ to $15.9 \pm 1.6$. arm circumference was $23.2 \pm 3.9-23.0 \pm 3.8$. the circumference of forearm was $20.8 \pm 2.5-20.6 \pm 2.5$. hand width was $7.8 \pm 0.8$ to $7.9 \pm 0.8$. The results of the biacromial width and bideltoid width measurements were $25.5 \pm 3.13$ and $39.2 \pm 4.7$. respectively. In the right and left upper extremities of students who did not do sports, arm length was $26.8 \pm 2.5-26.6 \pm 2.4$. forearm length was $23.3 \pm 2.1-23.3 \pm 2.0$. hand length was $16.0 \pm 1.5-16.2 \pm 1.5$. arm circumference was $22.4 \pm 3.5$ to $22.4 \pm 3.5$. circumference of forearm was $19.4 \pm 2.5-19.4 \pm 2.5$. hand width was $7.6 \pm 0.9-7.7 \pm 0.9$.

The results of the biacromial and bideltoid width measurements were $28.8 \pm 3.8$ and $37.6 \pm 4.4$. respectively. As a result of the evaluation made, there was a difference between arm circumference measurements $(p=0.02)$ when the measurements taken from the right and left extremities of the students who did sports and did not do sports were compared. It was observed that the difference between right - left arm length $(p=0.001)$ and right - left hand length $(p=0.02)$ was significant in the students who did not do sports. Playing basketball increases the arm circumference and forearm circumference in children.
\end{abstract}

Key words: Anthropometry, Basketball, Upper Extremity

\section{INTRODUCTION}

Medical science, aiming at human health, should evaluate the human being in a meaningful and socio-cultural environment to achieve this goal. The effect of sport exercises on body proportions has always been a subject of research. Anthropometry, which finds the most commonly used methods among the method used to determine the growth and development levels of children in the society. With anthropometric measurements it is possible to obtain samples of physical growth that occur until the end of the child's adolescence period. There is a close relationship between child growth and development and the general health and economic levels of the society. The most

important factors affecting physical growth and development in children are genetic features and environment. The best way to determine the results of these factors is to assess the children's well-being in terms of growth and development in each period (1).

There are social benefits in the sport's multi-faceted benefits to children's organism. Improves leadership and personality characteristics of children, for example from the moment of birth and on, some measurements are made on the human being (3.13). The 
height, head circumference, chest circumference and weight are the first values measured with birth. These measurements are regarded as indicators of baby's compliance with normal standards, development and nutrition level. As the child grows and develops gradually, it becomes a measure for shoes and clothes. In short, we measure and evaluate many dimensions related to our body in every period of life (4).

Anthropometric perimeter and length measurements are used in pediatrics, norm studies and assessment of body development. The growth of the body is followed by the transverse growth of the body to grow longitudinally. Middle childhood is the time to start school at the age of 7 in Turkey and it is an age when growth is widely considered (1). The purpose of the sport anthropometry is to investigate the general and specific conditions of the physical development changes, which are caused by the sporty fitness level of the athlete with respect to the body structure and the regular sporty training in accordance with the purpose. The determination of anthropometric and physiological profiles may contribute to the selection of criteria for achieving success for young basketball players. When the developmental profiles of young basketball players are followed, it is clear that the athlete's fitness with respect to the body structure and, physical development changes, general and special changes as a result of the regular sport training can be observed $(5,9)$.

In parallel with the change of environmental and social culture structures in our country, it is observed that families prefer popular sports in directing their children to sport. Since sport plays an important role in the multifaceted development and socialization of the child, it is recommended to start the sport at an early age. Children play games themselves while they are learning about their surroundings. When the child is between the ages of 6 and 11, when the child starts to relate to the people around him, the form of sports-type behavior occurs. If you are between the ages of 12-14, the child gets tired of this game-sport relationship and enters new quests. In this period, it requires technical rules that determine the use of gaming devices and the sport concept for the child begins. Teaching basketball in the age of development (ages 12-14) depends on a number of sensitive points. Young males who develop rapidly in terms of coordination, special movements, speed, and agility in pre-adolescence period, show pause in this period $(17,8)$.

Today, sport is defined as a more comprehensive definition of "movements that improve the state of health of a person and maintain improved health status". It is seen that sports from past to present day have an important place in society. The successes achieved in the international arena have been an important factor in people's sport orientation. Today, basketball and football have an important place, especially athletics, which is considered as the ancestor of all sports branches. For this reason, it is important to know the motor and anthropometric properties of the athletes in these branches and to create a branch specific athlete profile. Basketball is becoming popular with its dynamic features as a team sport today. It is a fun sport that all kinds of individuals with different genders and ages can easily do. Basketball is a team sport that develops physical qualities such as strength, speed, skill and mobility, and brings these features to a higher level during adulthood starting from childhood or youth $(15,19)$. Primary growth and body development is the fastest period $(10,11)$. Determining the potential performance in sports at an early age will lead the athletes to the correct sport and provide the optimum success. Regular physical activity is important for maintaining muscle strength, joint structure, joint function and bone health (20). It has been stated that even the colors of clothes create perceptual differences on individuals (21). It is accepted by many educators that sport plays a role in the development of personality and character traits (6).

This study, we aimed to show how development of children is affected by sports through measuring some body proportions of the children who play basketball and do not play during their developmental stages

\section{MATERIAL AND METHOD}

Students participating in the study were evaluated in two groups as students who played sports and who did not play sports. A total of 200 secondary school students participated in the study. Considering that the students have not undergone any surgical intervention for any disability while being 
assessed. Measurements of the right and left upper extremities of the students were taken with the help of a tape measure (Figure 1., 2. and 3.). The measurements were taken in accordance with the following definitions as a result of literature review.

The study Height Length: In normal anatomic position, the distance between bastion and vertex is measured.

Arm Length: The distance between the acromion and the olecranon was measured while the arm was in flexion 90.

Forearm Length: The distance between the olecranon and the stylus was measured while the arm was flexed 90 degrees.

Hand Length: The distance between stylus and acromelion is measured when the arm is brought to 90 flexion in a normal anatomical position.

Biacromial width: The distance between right and left acromion points was measured in normal anatomic position.

Bideltoid width: The distance between rightleft deltoid points is measured in normal anatomic position.

Hand Width: In the normal anatomic position, the distance between the distal ends of the second and fifth hand cardiac bones was measured.

Arm Circumference: In normal anatomic position, the gauze is measured on the line passing through the middle of the arm when the arms are slightly open to the side.

Forearm Circumference: In normal anatomic position, the arms were measured with a cloth tape measure on the line passing through the middle point of the forearm while slightly opened to the side.

Out of these measurements, height and weight measurements were also taken from the students.

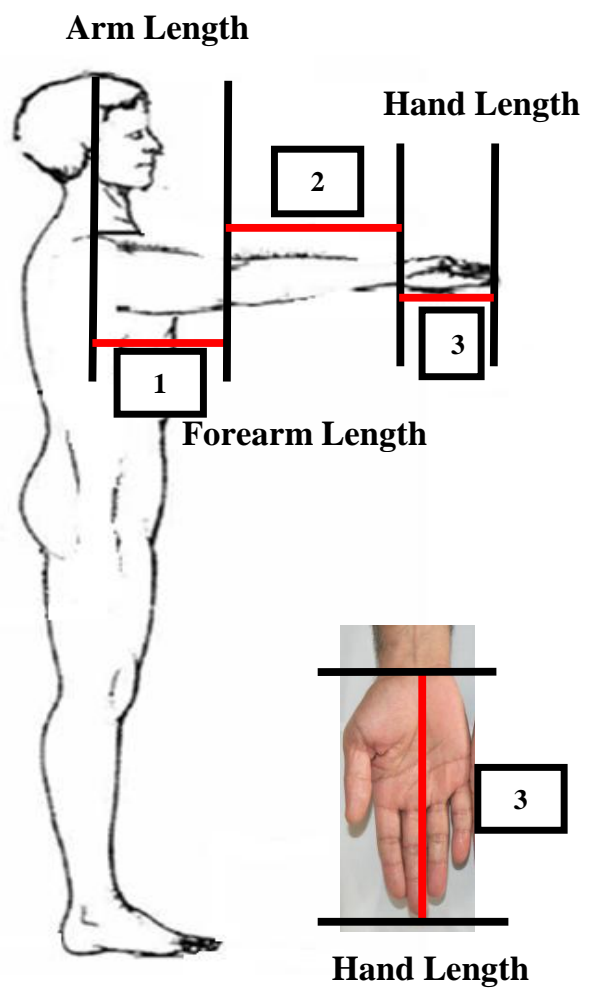

Figure 1: Measurements taken from the upper extremity; 1. Arm Length, 2. Forearm Length, 3. Hand Length

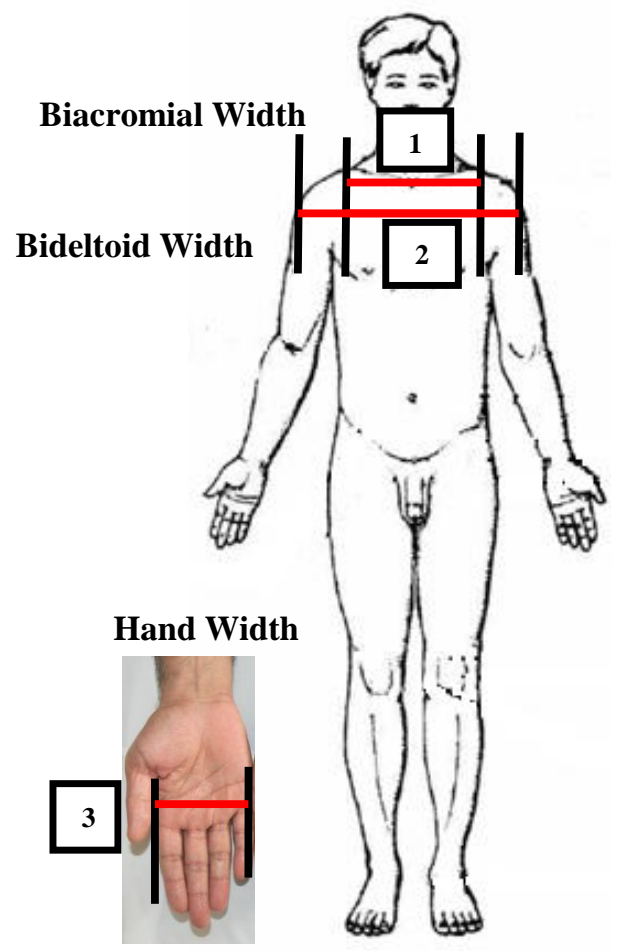

Figure 2: Measurements taken from the upper extremity; 1. Biacromial Width, 2. Bideltoid Width, 3. Hand Width 


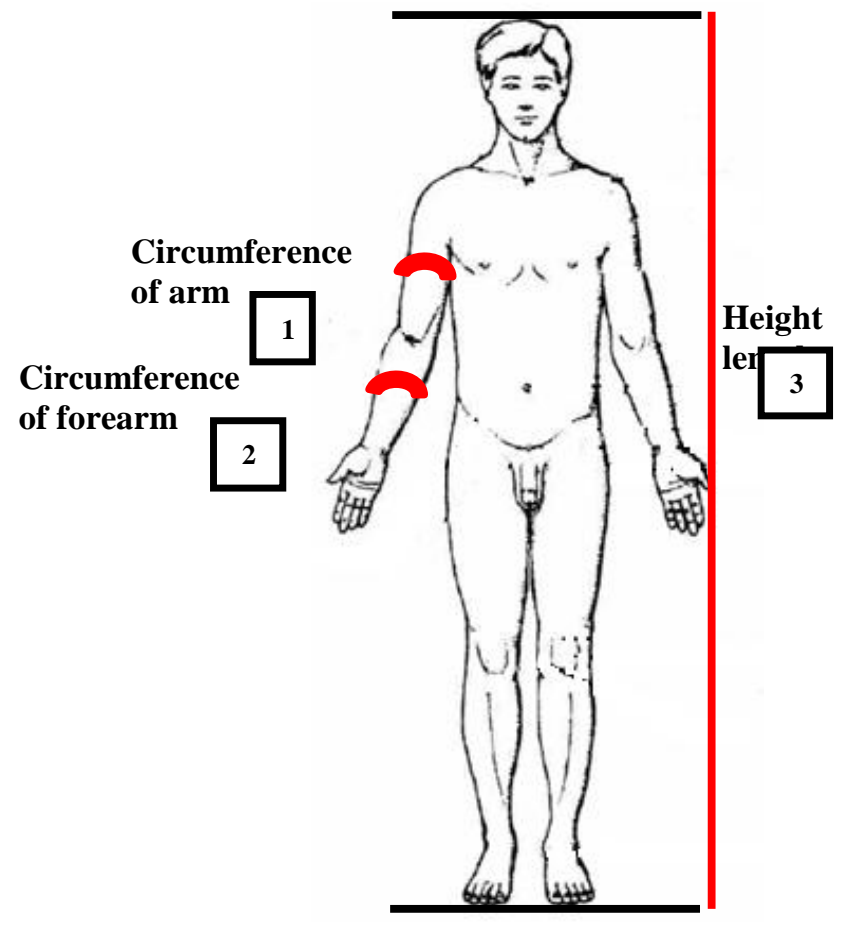

Figure 3: Measurements and height measurements taken from the upper extremity; 1 . Circumference of arm, 2. Circumference of forearm, 3. Height length

\section{Statistics}

All analyses of the study were performed by SPSS 22.0 (IBM Inc., IL, Chicago, USA) software. Descriptive statistics were calculated, and categorical variables as frequencies and percentages and continuous variables were presented as mean $\pm S D$ in tables. The normality assumption of continuous variables were detected by KolmogorovSmirnov test. Student t-test was used to compare two independent groups and two related samples. Chi-square test was used to determine the relation between categorical variables. In all analyses, $p$ value of less than 0.05 was considered as statistically significant result for $5 \%$ type- 1 error.

\section{Results}

200 secondary students participated to the study. When the measurement results were taken into account, the age range of the students who played and did not play basketball was $11 \pm 1.08$ and $11 \pm 0.8$, respectively. The average height of the students who played and did not play basketball; were $153.5 \pm 12.9-149.2 \pm 8.1 \mathrm{~cm}$ and the weight was $46.7 \pm 12.04-43.08 \pm 12.9 \mathrm{~kg}$ respectively (Table 1 ).

\begin{tabular}{|l|l|l|}
\hline \multicolumn{2}{|c|}{$\begin{array}{l}\text { Table 1: Average height and weight of students } \\
\text { who played and did not play basketball }\end{array}$} \\
\hline & $\begin{array}{l}\text { Played } \\
\text { Basketball }\end{array}$ & $\begin{array}{l}\text { Did not Play } \\
\text { Basketball }\end{array}$ \\
\hline Height Lenght & $153.5 \pm 12.9 \mathrm{~cm}$ & $149.2 \pm 8.1 \mathrm{~cm}$ \\
\hline Weight & $46.7 \pm 12.04 \mathrm{~kg}$ & $43.08 \pm 12.9 \mathrm{~kg}$ \\
\hline
\end{tabular}

In the right and left upper extremities of students who played Basketball; arm length was $28,4 \pm 3,1 \mathrm{~cm}-28,4 \pm 3,01 \mathrm{~cm}$, forearm length was $24,1 \pm 2,4 \mathrm{~cm}-24,1 \pm 2,4 \mathrm{~cm}$, hand length was $15,9 \pm 1,8 \mathrm{~cm}-15.9+-1.6 \mathrm{~cm}$, arm circumference $23.2 \pm 3.9 \mathrm{~cm}-23.0 \pm 3.8 \mathrm{~cm}$, circumference of forearm $20.8 \pm 2.5 \mathrm{~cm}-20.6 \pm$ $2.5 \mathrm{~cm}$, hand width was $7,8 \pm 0,8 \mathrm{~cm}-7,9 \pm 0,8$ $\mathrm{cm}$. Biacromial width and bideltoid width measurement results were measured as $25.5 \pm$ $3.13 \mathrm{~cm}$ and $39.2 \pm 4.7 \mathrm{~cm}$, respectively (Table 2).

\begin{tabular}{|c|c|c|}
\hline & $\begin{array}{l}\text { Right upper } \\
\text { extremities }\end{array}$ & $\begin{array}{l}\text { Left upper } \\
\text { extremities }\end{array}$ \\
\hline Arm length & $28.4 \pm 3.1 \mathrm{~cm}$ & $28.4 \pm 3.01 \mathrm{~cm}$ \\
\hline Forearm length & $24.1 \pm 2.4 \mathrm{~cm}$ & $24.1 \pm 2.4 \mathrm{~cm}$ \\
\hline Hand length & $15.9 \pm 1.8 \mathrm{~cm}$ & $15.9 \pm 1.6 \mathrm{~cm}$ \\
\hline $\begin{array}{l}\text { Arm } \\
\text { circumference }\end{array}$ & $23.2 \pm 3.9 \mathrm{~cm}$ & $23.0 \pm 3.8 \mathrm{~cm}$ \\
\hline $\begin{array}{l}\text { Forearm } \\
\text { circumference }\end{array}$ & $20.8 \pm 2.5 \mathrm{~cm}$ & $20.6 \pm 2.5 \mathrm{~cm}$ \\
\hline Hand width & $7.8 \pm 0.8 \mathrm{~cm}$ & $7.9 \pm 0.8 \mathrm{~cm}$ \\
\hline $\begin{array}{l}\text { Biacromial } \\
\text { width }\end{array}$ & \multicolumn{2}{|c|}{$25.5 \pm 3.13 \mathrm{~cm}$} \\
\hline Bideltoid width & \multicolumn{2}{|c|}{$39.2 \pm 4.7 \mathrm{~cm}$} \\
\hline
\end{tabular}

In the right and left upper extremities of students who did not play Basketball; arm length was $26.8 \pm 2.5 \mathrm{~cm}-26.6 \pm 2.4 \mathrm{~cm}$, forearm length was $23.3 \pm 2.1 \mathrm{~cm}-23.3 \pm 2.0 \mathrm{~cm}$, hand length was $16.0 \pm 1.5 \mathrm{~cm}-16.2 \pm 1.5 \mathrm{~cm}$, arm circumference was $22.4 \pm 3.5 \mathrm{~cm}-22.4 \pm 3.5 \mathrm{~cm}$, forearm circumference was $19.4 \pm 2.5 \mathrm{~cm} \mathrm{-}$ $19.4 \pm 2.5 \mathrm{~cm}$, hand width was $7.6 \pm 0.9 \mathrm{~cm}-$ $7.7 \pm 0.9 \mathrm{~cm}$ respectively. The results of biacromial and bideltoid width measurements were $28.8 \pm 3.8 \mathrm{~cm}$ and $37.6 \pm 4.4 \mathrm{~cm}$, respectively (Table 3 ). 
Table 3: Measurements taken from the upper left and right extremities of students who did not play basketball

\begin{tabular}{|l|c|c|}
\hline & Right upper extremities & Left upper extremities \\
\hline Arm length & $26.8 \pm 2.5 \mathrm{~cm}$ & $26.6 \pm 2.4 \mathrm{~cm}$, \\
\hline Forearm length & $23.3 \pm 2.1 \mathrm{~cm}$ & $23.3 \pm 2.0 \mathrm{~cm}$ \\
\hline Hand length & $16.0 \pm 1.5 \mathrm{~cm}$ & $16.2 \pm 1.5 \mathrm{~cm}$ \\
\hline Arm circumference & $22.4 \pm 3.5 \mathrm{~cm}$ & $22.4 \pm 3.5 \mathrm{~cm}$, \\
\hline Forearm circumference & $19.4 \pm 2.5 \mathrm{~cm}$ & $19.4 \pm 2.5 \mathrm{~cm}$, \\
\hline Hand width & $7.6 \pm 0.9 \mathrm{~cm}$ & $7.7 \pm 0.9 \mathrm{~cm}$ \\
\hline Biacromial width & \multicolumn{2}{|c|}{$28.8 \pm 3.8 \mathrm{~cm}$} \\
\hline Bideltoid width & $37.6 \pm 4.4 \mathrm{~cm}$ \\
\hline
\end{tabular}

According to the results obtained in the comparison between groups in the result of statistical evaluation; the differences between right arm lengths $(\mathrm{p}=0.000)$ and left arm lengths $(\mathrm{p}=0.000)$. right forearm lengths $(\mathrm{p}=0.027)$ and left forearm lengths $(p=0.044)$. right hand widths $(\mathrm{p}=0.033)$. right forearm peripheral widths $(p=0.001)$ and left forearm peripheral widths $(p=0.001)$ were significant $(p<0.05)$.
As a result of the evaluation made. there was a difference between arm circumference measurements $(p=0.02)$ when the measurements taken from the right and left extremities of the students who did sports and did not do sports were compared. It was observed that the difference between right - left arm length $(\mathrm{p}=$ $0.001)$ and right - left hand length $(p=0.02)$ was significant in the students who did not do sports.

\begin{tabular}{|c|c|c|c|c|}
\hline & & Mean & Std. Deviation & t-test \\
\hline \multirow[t]{2}{*}{ Arm circumference (right) } & Basketball players & 23.02 & 1.74 & \multirow[t]{2}{*}{$2.24^{*}$} \\
\hline & Not Basketball players & 22.04 & 1.82 & \\
\hline \multirow[t]{2}{*}{ Arm circumference (left) } & Basketball players & 23.00 & 1.70 & \multirow[t]{2}{*}{$2.19^{*}$} \\
\hline & Not Basketball players & 22,04 & 1,82 & \\
\hline \multirow[t]{2}{*}{ Forearm circumference (right) } & Basketball players & 20.8 & 2.14 & \multirow[t]{2}{*}{$3.03^{*}$} \\
\hline & Not Basketball players & 19.40 & 1.66 & \\
\hline \multirow[t]{2}{*}{ Forearm circumference (left) } & Basketball players & 20.60 & 2.47 & \multirow[t]{2}{*}{$2.41^{*}$} \\
\hline & Not Basketball players & 19.40 & 1.66 & \\
\hline
\end{tabular}

\section{Discussion}

For Each sport is known to have its own characteristic. The athletes with special physicalbuilt suitable to branches, it is known that their features are effective in competition. Successful athletes may be a model for knowing the physical characteristics of talent selection. It is important to make physical measurements such as length, environment, etc. (18). We aimed to reveal the differences in the individuals doing the sports with the length and the environmental measurements we made in the students who did and did not do sports, and to be able to model the physical features.
In a study by Kılınç (12), length and width measurements were taken in a group of students who had an average age of 14 in rowing. For students with high and low rowing performance, mean height length was $145.8 \pm 3.5$ and $139.9 \pm 3.5$, weight was $36.4 \pm 7.0$ and $33.7 \pm 4.4 \mathrm{~kg}$, arm length was $46.3 \pm 4.4$ and $43.2 \pm 5.1 \mathrm{~cm}$, forearm length was $22.3 \pm 1.2$ and $21.2 \pm 1.6$, hand length was 15.7 \pm 0.7 and $15.1 \pm 0.8$, respectively. When we compared the results with our study, it was observed that there was a difference between the measurements with the exception of hand length. It is believed that this difference is due to sports in different branches and to different age groups. In this case it is shown that there are differences in 
extremity lengths depending on different sports branches (12). In the study conducted by Bektaş and colleagues (2), anthropometric measurements were taken from individuals with a mean age of $13.84+4.34$. From the measurements they have taken, the biceps circumference is measured in terms of tiny, star, young, big categories was determined as $22.1 \pm 1.9,22.8 \pm 1.7,24.5 \pm 3.1$ and $29.1 \pm 8.0$, respectively. In our study, it was observed that the comparison with the individuals playing basketball was compatible with the tiny, star and young categories.

Mahakizadeh and his colleagues (14) have taken hand length measurements from individuals aged 18-25 years. According to the results obtained, the average hand length measurement was $21.21 \mathrm{~cm}$. It is seen that when we make comparisons for the individuals who do sports and those who do not in our study, there is a difference. This was thought to be due to the age difference of the individuals (14).

Erol and his colleagues have taken some anthropometric measurements to evaluate the body fat pattern and somatotype from 16-year-old basketball star national team players. From these measurements, the arm circumference measurement result average was determined as $27.32 \mathrm{~cm}$. We observed that the result we obtained in our study was lower due to the age difference (7). In the study conducted by Pazarözyurt and

\section{REFERENCES}

1. Altıntaş,. Akdoğan I., Özdemir B., Hasusta A. et al. Denizli merkez ilköğretim 1.sınıf (7 yaş) öğrencilerinde antropometrik vücut çevre ve üst ekstremite uzunluk ölçümleri. S.D.Ü. Tip Fak. Derg. 2005; 12(4): 14-18.

2. Bektaş Y., Koca ÖB., Gültekin T., Sağır M., Akın G. Bayan basketbolcuların antropometrik özellikleri: somatotip ve vücut bileşimi değerleri. Niğde Üniversitesi Beden Eğitimi ve Spor Bilimleri Dergisi. 2007; 2(1): 52-62.

3. Çetinkaya G., İmamoğlu G. Research on Leadership Tendency of Students Taking Sports Education According Difference Variations, The Journal of International Social Research, 2018; 59(11): 719-725.

4. Çıkmaz S., Taşkınalp O., Uluçam E et al. Anthropometric measurements and proportions of body constitution in football players. Trakya Üniversitesi Tip Fakültesi Dergisi 2005; 22(1): 32-36.

5. Çimen O., Cıcıŏ̆lu İ., Günay M. Erkek ve bayan türk genç milli masa tenisçilerinin fiziksel ve fizyolojik profilleri. Bed. Eğt. Spor Bil Der. 1997; 4: 7-12

6. Ermiş E., Ermiş A., İmamaoğlu O. Erişkinlik Aşamasında Öğrencilerde Spor ve Çoklu Zeka İlişkisi, Turkish Studies Social Sciences, 2018; 13(18): 589-598, DOI Number: http://dx.doi.org/10.7827/TurkishStudies.14093 colleagues (16), anthropometric measurements of elite female basketball players were taken. Individuals who are included in the evaluation are between the ages of 23-25. The averages of the hand lengths of the players who played in different positions were $19.24 \pm 0.68,20.2 \pm 0.82$, and $21.04 \pm 1.34 \mathrm{~cm}$, respectively, in the playmaker, striker and pivot positions (16). It was found meaningful that basketball players had larger arm circumference and forearm circumference than not Basketball players $(\mathrm{p}<0.05)$.

\section{Conclusion}

In this study we have tried to reveal the differences between the upper extremity measurements of the students who played basketball and did not play basketball and at the same time we tried to reveal characteristic upper extremity measurements in the 11-years old average. Playing basketball increases the arm circumference and forearm circumference in children. Based on our literature review, we have observed that the upper extremity measurements are not frequently compared in the studies on the individuals who do and do not do sport. Thus, we believe that our study will be a reference for this age range.

7. Erol AE., Ayan V., Mülazımoğlu O., Koçak M. Basketbol yıldız milli takım (16 yaş) oyuncularının vücut yağ örüntüsü ve somatotip değerlerinin tespiti. e-Journal of New World Sciences Academy2008; 3(2): 108-115.

8. Hamamioğlu Ö., Kaya Y. Basketbol sporunun 7-12 yaşlarındaki erkek çocuklarındaki boy-kilo ve vücut yă̆ oranına etkisi. Niğde Üniversitesi Beden Eğitimi ve Spor Bilimleri Dergisi. 2008; 2(3): 182-192.

9. Hoare DG. Predicting success in junior elite basketball players - the contribution of anthropometic and physiological attributes. J Sci Med Sport. 2000; 3(4): 391-405.

10. İmamoğlu O., Yamak B., Çebi M., İslamoğu İ. Antropometric and Motoric Characteristics of Certain Selected Primary School Student Wrestlers, The Journal of International Social Research, 2018; 59(11): 1463-1468.

11. İmamoğlu, O., \& Çoknaz, H. İlköğretim programlarında yer alan beden eğitimi dersleri ile öğrencilerin fiziksel gelişimlerinin araştırılması. Atatürk Beden Eğitimi ve Spor Bilimleri Dergisi, 2002; 4(2): 5-11.

12. Kılınç F. Çocuklarda ekstiremite uzunluk ve çevre ölçümlerinin kürek çekme performansý üzerine etkileri. S.D.Ü. Tip Fak. Derg. 2008; 15(3): 30-33.

13. Koca F., İmamoğlu G., İmamoğlu O. Sports Status of High School Students and Investigation of Personality 
Characteristics by Gender, The Journal of Academic Social Science, 2018; 80: 31-42

14. Mahakizadeh S., Moghani-Ghoroghi F., Moshkdanian Gh et al. The determination of correlation between stature and upper limb and hand measurements in Iranian adults. Forensic Science International 2016; 260: 27-30.

15. Narazaki K., Berg K., Stergiou N., Chen B. Physiological demands of competitive basketball. Scand J Med Sci Sports 2009; 19: 425-432.

16. Pazarözyurt İ., İnce G. Elit bayan basketbolcularda antropometrik özellikler, dikey sıçrama ve omurga esnekliğinin mevkilere göre incelenmesi. Spormetre Beden Eğitimi ve Spor Bilimleri Dergisi: 2009; VII(1): 9-18.

17. Sarıtaş N., Yıldız K., Hayta Ü. İlkokul Öğrencilerinin Bazı Motorik ve Fizyolojik Özelliklerinin Karşılaştırılması. CBÜ Beden Eğitimi ve Spor Bilimleri Dergisi 2017; 12 (2): 117-127.
18. Slater GJ., Rice AJ., Mujika I et al. Physique traits of lightweight rowers and their relationship to competitive success. Br J Sports Med 2005; 39: 736-741.

19. Usgu S. Profesyonel basketbol oyuncularında fonksiyonel eğitimin performansla ilişkili fiziksel uygunluk parametrelerine etkisi. T.C Hacettepe Üniversitesi Sağlık Bilimleri Enstitüsü. ANKARA, 2015.

20. Yamak B. İmamoğlu O., İslamoğlu İ., Çebi M. The Effects of Exercise on Body Posture, Turkish Studies Social Sciences 2018; 13(18): 1377-1388. DOI Number: http://dx.doi.org/10.7827/TurkishStudies.13911

21. Yamaner F., İmamoğlu G. Sport Performance Colors Power and Effect, Turkish Studies 2018; 13(15): 509-520, DOI Number:http://dx.doi.org/10.7827/TurkishStudies.13602 